\title{
PENGARUH KEBIJAKAN PEMBIAYAAN DALAM MENINGKATKAN KINERJA KEUANGAN PERBANKAN SYARIAH: STUDI EMPIRIS PADA PERBANKAN SYARIAH DI INDONESIA
}

\author{
Sutrisno \\ Universitas Islam Indonesia
}

\begin{abstract}
The development of Islamic banking in Indonesia is characterized by rapidly increasing assets, third party funds, and financing. Islamic banks as financial intermediaries are required to be able to distribute the funds in the form of financing to communities who need of funds. Due to the funding provided is supposed to increase bank profits. The purpose of this study is to analyze and examine the role of financing decisions to financial performance on Islamic banking. In this study the financial performance measured by return on equity (ROE) and Net Profit Margin (NPM) as the dependent variable, while the independent variables are cinsist of mudharaba financing (MUD), Musharaka financing (MUS), murabaha financing (MUR), Ijara financing (IJR), and qordul hasan financing (QORD). We also use firm size as a control variable. Samples in this study were eight islamic banks in Indonesia. We use multiple regression analyzes with the aid program as E-views, with a significance level of 5\%. The results showed that variable of musharaka financing, murabaha financing, and firm size have a significant effect on profitability. While variable of mudaraba financing, ijara financing and qord financing no significant effect on islamic bank performance.
\end{abstract}

Keywords:

Return on Equity, Net Profit Margin, Mudaraba, Musharaka, Murabaha, Ijarah, Qordul Hasan 


\section{PENDAHULUAN}

Semenjak bank islam didirikan pertama kali di Mesir pada tahun 1963, perkembangan bank islam di dunia menunjukkan perkembangan yang mengembirakan (Haron dan Ahmad, 2000). Sampai saat ini sudah lebih dari 170 bank islam termasuk jasa keuangan islam dan diperkirakan jumlah ini akan semakin meningkat (Muhammad, 2000).

Demikian pula dengan perkembangan lembaga perekonomian islam di Indonesia akhir-akhir ini sangat pesat. Hal ini ditandai dengan banyak berdirinya lembaga-lembaga keuangan islam, seperti bank syariah, asuransi syariah, pegadaian syariah, pasar modal syariah, bahkan produkproduk syariah seperti obligasi syariah juga sudah banyak beredar di Indonesia. Perkembangan lembaga perekonomian islam di Indonesia akhir-akhir ini sangat pesat. Hal ini ditandai dengan banyak berdirinya lembaga-lembaga keuangan islam, seperti bank syariah, asuransi syariah, pegadaian syariah, pasar modal syariah, bahkan produkproduk syariah seperti obligasi syariah juga sudah banyak beredar di Indonesia.

Perkembangan lembaga keuangan syariah ditandai dengan berdirinya bank islam pertama di Indonesia pada 2 Mei 1992 yang diprakarsai oleh Majelis Ulama Indonesia (MUI) yakni Bank Muamalat Indonesia (BMI). Berdirinya Bank Muamalat Indonesia ini segera diikuti oleh lembaga keuangan syariah yang lain seperti asuransi syariah, pegadaian syariah, dan produkproduk syariah lainnya seperti obligasi syariah, reksadana syariah bahkan telah berdiri pasar saham syariah.

Perbankan syariah telah terbukti keandalannya setelah perekonomian Indonesia diterpa krisis keuangan pada tahun 1997/1998. Pada saat krisis tersebut semua bank konvensional mengalami kerugian bahkan banyak diantaranya yang akhirnya dilikuidasi, tetapi BMI tetap berjalan dengan baik bahkan masih bisa membukukan keuntungan.

Bank islam yang sudah teruji keandalaanya tersebut, mendorong perbankan konvensional untuk mendirikan cabang syariah yang sering disebut Unit Usaha Syariah (UUS). Apalagi pemerintah memberikan lampu hijau atas pendirian unit usaha syariah oleh bank konvensional, sehingga banyak bank konvensional yang membuka unit usaha syariah. Pada tahun 2005 jumlah bank umum syariah masih 3 bank dengan jumlah kantor 304 dan pada tahun 2011 sudah mencapai 11 bank umum dengan 1.349 kantor, sementara jumlah unit usaha syariah relatif stagnan bahkan terjadi penurunan karena telah menjadi bank umum syariah. Perkembangan BPR syariah juga sangat pesat di mana ada 92 BPRS pada tahun 2005 dengan 92 kantor menjadi 154 BPRS tahun 2011 dengan 362 kantor. Dengan demikian jumlah kantor bank syariah pada tahun 2005 sebesar 550 kantor menjadi 2.011 kantor pada September 2011.

Demikian juga dengan pertumbuhan aset yang pada tahun 2007 aset perbankan syariah masih sebesar Rp 37,80 trilyun, pada akhir september sudah mencapai Rp 126,65 trilyun, artinya aset tumbuh selama 5 tahun sebesar $235 \%$ atau rata pertumbuhan per tahun 67\%. Pertumbuhan simpanan masyarakat atau sering disebut dana pihak ketiga (DPK) sebagai indikator bahwa bank disukai masyarakat juga meningkat signifikan. DPK pada akhir tahun 2007 masih sebesar Rp 28,73 trilyun, pada akhir september 2011 sudah meningkat menjadi Rp 99,67 trilyun, artinya selama 5 tahun DPK tumbuh $247 \%$ atau rata-rata per tahun $69 \%$. Sementara itu dari segi pembiayaan pertumbuhannya juga hampir sama dengan pertumbuhan aset dan DPK. Pembiayaan yang diberikan perbankan syariah pada tahun 
2007 sebesar Rp 28,84 trilyun meningkat menjadi Rp 95,40 trilyun pada akhir september 2011. Ini berarti selama lima tahun pembiayaan perbankan syariah meningkat $231 \%$ atau rata-rata tumbuh $66 \%$ per tahun.

Bank syariah merupakan lembaga komersial yang dalam operasinya berorientasi mencari keuntungan. Sebagai lembaga perbankan, bank syariah mempunyai fungsi untuk menghimpun dana dari masyarakat dan menyalurkannya kepada masyarakat melalui pembiayaan. Pembiayaan yang diberikan bank syariah kepada nasabahnya didasarkan atas tiga prinsip.

Pertama berdasar atas prinsip bagi hasil atau profit sharing, yakni pembiayaan dari bank islam di mana nasabah mengembalikan pokok pinjamannya disertai dengan bagi hasil keuntungan yang diperoleh nasabah. Pada pembiayaan berdasar prinsip bagi hasil terdiri dari dua skema pembiayaan yakni pembiayaan mudharabah dan pembiayaan musyarakah. Mudharabah merupakan akad kerjasama usaha antara dua pihak dimana pihak pertama yakni pihak bank (shahibul maal) menyediakan seluruh dana yang dibutuhkan, sedangkan puhak lain (nasabah) menjadi pengelola (Sudarsono, 2003: 65). Jika mendapatkan keuntungan maka keuntungan tersebut dibagi sesuai dengan nisbah bagi hasil yang disepakati, demikian juga bila mengalami kerugian juga akan dibagi. Sedangkan musyarakah merupakan pembiayaan dari bank islam kepada nasabah di mana bank menyediakan sebagian dana usaha sedangkan sebagian lainnya disediakan oleh nasabah. Dalam pembiayaan ini bank boleh ikut serta alam manajemen (Siamat, 1999:131). Profit sharing ini inilah yang pada dasarnya merupakan produk asli syariah (Suyanto, 2007), sebab pembiayaan ini benar-benar merupakan pembiayaan berkeadilan, artinya jika ada keuntungan maka keuntungan akan dibagi sesuai kesepakatan, demikian pula bila terjadi kerugian maka kerugian juga akan dibagi.

Kedua, pembiayaan berdasarkan prinsip mark-up atau juga disebut dengan prinsip jual beli (perdagangan). Bank sebagai pemberi pembiayaan akan membeli barang sesuai yang diinginkan nasabah yang kemudian barang tersebut dijual kepada nasabah dengan me-mark up atau menambah margin laba pada harga barang tersebut. Ada beberapa jenis pembiayaan dengan prinsip jual beli ini, yakni (1) pembiayaan murabahah yakni jual beli barang pada harga asal dengan tambahan keuntungan yang disepakati antara pihak bank dengan nasabah (Sudarsono, 2003: 58). Pada perjanjian murabahah, bank membiayai pembelian barang yang dibutuhkan nasabah dengan membeli barang dari pemasok, dan kemudian menjualnya kepada nasabah dengan menambah marjin keuntungan. (2) pembiayaan al-bai'bitsaman ajil yakni pembiayaan dari bank islam kepada nasabah untuk jangka panjang dengan sistem pembayaran angsuran (Siamat, 1999:131).

Ketiga, pembiayaan berdasar konsep sewa seperti leasing pada lembaga keuangan konvensional. Ijarah adalah pemindahan hak guna atas suatu barang dan atau jasa atas pembayaran upah sewa tanpa diikuti dengan pemindahan kepemilikan barang itu sendiri dengan perkataan lain ijarah adalah mengambil manfaat atas suatu barang dengan jalan penggantian sewa atas upah sejumlah tertentu. Dalam konteks perbankan atau lembaga keuangan syariah, Ijarah adalah lease contract di mana suatu bank atau lembaga keuangan menyewakan peralatan kepada nasabahnya dengan membebankan biaya yang sudah ditentukan secara pasti sebelumnya (Sudarsono, 2003: 62) 
Keempat, pembiayaan dengan prinsip sosial, yakni pembiayaan yang tidak dikenai tambahan biaya apapun kecuali biaya administrasi. Jenis pembiayaan ini sering disebut pembiayaan al-qordul hasan. Pada pembiayaan qordul hasan ini nasabah tidak dibebani biaya apapun dan hanya berkewajiban membayar sebesar pokok pinjamannya saja. Sumber dana yang digunakan untuk pembiayaan ini biasanya diambilkan dari zakat, infaq dan sodaqah serta dari pos non halal dari bank.

Pendapatan yang diperoleh oleh bank mayoritas berasal dari pembiayaan, sehingga pada bank islam tumpuan untuk mendapatkan keuntungan juga banyak berasal dari pembiayaan yang diberikan. Kinerja keuangan perusahaan bisa dilihat dari keuntungan yang diperoleh yang biasanya dibandingkan dengan sumber dana yang digunakan. Oleh karena itu peneliti bermaksud menguji seberapa besar peran pembiayaan terhadap kemampu-labaan perbankan Islam.

\section{TINJAUAN PUSTAKA}

Lembaga perbankan sangat dibutuhkan oleh masyarakat baik masyarakat yang mempunyai uang sebaragai sara penyimpan uang maupun masyarakat yang membutuhkan dana dalam rangka mencari pembiayaan (kredit). Menurut Undangundang No. 10 tahun 1998 tentang perubahan atas Undang-undang No. 7 tahun 1992 dalam pasal 1 ayat 1 menyebutkan pengertian bank adalah 'Bank adalah badan usaha yang menghimpun dana dari masyarakat dalam bentuk simpanan dan menyalurkannya kepada masyarakat dalam bentuk kredit dan atau bentuk-bentuk lainnya dalam rangka meningkatkan taraf hidup rakyat banyak'. Pengertian tersebut menegaskan bahwa fungsi utama bank adalah sebagai perantara keuangan yakni menghimpun dana dari masyarakat dan menyalurkannya kepada masyarakat dalam bentuk kredit atau bentuk lainnya.

Perbankan baik bank umum maupun bank perkreditan rakyat dalam melaksanakan operasionalnya bisa memilih dasar kegiataannya, apakah menggunakan kegiatan usaha secara konvensional dan atau berdasarkan prinsip syariah. Bank konvensional dalam menjalankan kegiatannya menggunakan instrumen bunga sementara bank syariah secara tegas dilaranga menggunakan instrumen bunga dalam melaksanakan kegiatannya. Rivai et al. (2007:733) menyebutkan bahwa Bang Syariah adalah bank yang melaksanakan kegiatan usahanya berdasarkan prinsip syariah, yaitu aturan perjanjian berdasarkan hukum islam antara bank dengan pihak lain baik untuk penyimpanan dana atau pembiayaan kegiatan usaha, atau kegiatan lainnya yang dinyatakan sesuai dengan syariah.

Dana yang diperoleh oleh bank syariah, selain ditempatkan pada aset yang tidak menguntungkan (non earning assets) seperti untuk mendirikan atau menyewa bangunan, membeli peralatan, cadangan likuiditas, maka dana bank yang paling banyak akan digunakan untuk disalurkan kepada masyarakat. Dana yang disalurkan kepada masyarakat untuk bank konvensional disebut dengan kredit, sementara bagi bank syariah agar tidak terkesan kredit identik dengan bunga maka dana yang disakurkan kepada masyarakat disebut sebagai pembiayaan.

Di samping prinsip tersebut, bank syariah juga memberikan pembiayaan dengan tujuan membantu para kaum dhuafa yang dilakukan dengan prinsip sosial.

- Prinsip jual beli

Prinsip jual ini pada daasarnya menambahkan marjin harga atas harga barang yang menjadi obyek pembiayaan. 
Bersarnya marjin laba yang ditambahkan berdasarkan negosiasi antara bank dengan nasabah. Adapun jual beli yang dijadikan dasar adalah untuk pembiayaan modal kerja maupun investasi, yaitu:

- Bai’ Al-Murabahah

Pada pembiayaan ini bank membiayai pembelian barang yang diperlukan nasabah dengan sistem pembayaran kemudian (Muhammad, 2005: 94). Dalam pelaksanaannya bank dan nasabah melakukan negosiasi besarnya marjin laba, setelah disepakati dilakukan akad jual beli berikut cara dan syarat pembayarannya.

- Pembiayaan Salam

Pembiayaan yang diberikan oleh bank islam kepada nasabah dengan dengan cara penyerahan barang ditangguhkan. Nasabah sebagai penjual barang dan bank sebagai pembeli barang. Bank membayar tunai diawal atas barang nasabah, sementara barangnya akan dikrimkan belakangan. Dalam transaksi ini sudah harus ada kesepakatan tentang kuantitas, kualitas, harga dan waktu penyerahannya (Muhammad, 2005:94).

- Prinsip Bagi Hasil

Prinsip bagi hasil atau profit sharing merupakan murni permbiayaan yang seharusnya dilakukan oleh bank islam. Ada dua jenis pembiayaan berdasar bagi hasil, yakni:

\section{- Al-Mudharabah}

Mudharabah merupakan kerjasama antara pemilik dana (shahibil mal) dengan pengusaha (mudharib) yang mempunyai proyek dan mengelolanya. Aplikasinya dalam perbankan syariah menjadi pembiayaan mudharabah yakni pembiayaan dari bank islam kepada nasabah dimana bank menyediakan semua kebutuhan dana sementara nasabah menyediakan proyek dan manajemen (Muhammad, 2005:98).
Bank islam dalam hal ini tidak boleh ikut dalam manajemennya, tetapi mempunyai hak untuk mengusulkan dan melakukan pengawasan. Jika terjadi kerugian karena kelalaian pengelola maka kerugian ditanggung pemilik dana sementara, jika kerugian tersebut karena kelalaian pengelola, misalnya terjadi kecurangan. Maka pengelola harus bertanggung jawab.

- Al-Musyarakah

Musyarakah merupakan kerjasama antar dua pihak atu lebih untuk suatu usaha tertentu dimana masing-masing pihak memberikan kontribusi dana dengan keuntungan dan risiko akan ditanggung bersama sesuai dengan kesepakatan (Sudarsono, 2003:63). Dalam perbankan islam diaplikasikan menjadi pembiayaan musyarakah yakni pembiayaan yang diberikan oleh bank islam kepada nasabah dengan cara bank menyediakan sebagian dana, sementara nasabah juga menyediakan sejumlah dana. Dengan demikian pembiayaan ini merupakan kerjasama usaha yang ditanggung bersama. Bank islam dalam pembiayaan ini boleh ikut dalam manajemen, sehingga pada pembiayaan konvensional seperti modal ventura sementara yang membedakan pada pembiayan pada modal ventura pada saat tertentu modal ventura harus ditarik dari usaha nasabah. Keuntungan yang diperoleh dibagi dengan sesuai kesepakatan.

- Prinsip Sewa

Prinsip sewa ini seperti leasing atau sewa guna pada lembaga pembiayaan konsumen. Pembiayaan dengan prinsip sewa di bank islam disebut ijarah, yakni akad pemindahan hak guna barang atau jasa tanpa diikuti dengan hak milik atas barang yang bersangkutan. Dalam operasinya ijarah adalah lease contract dimana bank yang menyewakan peralatan 
kepada nasabahnya berdasarkan pembebanan biaya yang sudah ditentukan secara pasti sebelumnya (Darsono, 2003:62).

- Prinsip Sosial

Selain beroperasi mencari keuntungan, bank syariah juga diperkenankan untuk melakukan kegiatan sosial. Pelaksanaan fungsi sosial ini, juga dapat merefleksikan peranan perbankan syariah dalam pemerataan kesejahteraan ekonomi umat. Hal ini sesuai dengan UU No. 21 Tahun 2008 tentang Perbankan Syariah, dimana Bank Syariah dan Unit Usaha Syariah (UUS) dapat menjalankan fungsi sosial, yaitu menerima dana yang berasal dari zakat, infak, sedekah atau dana sosial lainnya dan menyalurkannya kepada organisasi pengelola zakat.

Selain menerima dana yang berasal dari zakat, infaq dan sodaqah, bank syariah dan UUS juga dapat menghimpun dana yang berasal dari wakaf uang dan menyalurkannya kepada pengelola wakaf (nazhir) sesuai kehendak pemberi wakaf (wakif).

Sudah banyak penelitian tentang faktor-faktor yang menentukan profitabilitas seperti Haron (1996) yang melakukan penelitian dibeberapa negara Arab, menggunakan total income to total asset (TITA) untuk mengukur profitabilitas. Akhter and Sadaqad (2011), Zeitun (2012), Kuppusany and Samudram (2010), Gul et.al (2011) dan Moin (2008) menggunakan return on assets (ROA) dan return on equity (ROE) untuk megukur profitabilitas. Sementara Srairi (2009) yang melakukan penelitian bank islam di negara-negara teluk (GCC) menggunakan proksi return on assets (ROA) untuk mengukur profitabilitas. Selain Srairi (2009), yang menggunakan ROA sebagai proksi profitabilitas adalah Izhar and Auutay (2007), Rahman and Rochmanika (2012), Al-Qomar and Al-Mutairi (2008) dan Syafri (2012).
Haron (1996) melakukan penelitian terhadap 13 bank islam di beberapa negara Arab untuk mengetahui faktor-faktor yang mempengaruhi profitabilitas., menggunakan 15 variabel yang diduga mempengaruhi profitabilitas. Salah satu penemuannya adalah pembiayaan berdasar mark-up dan pembiayaan berdasar bagi hasil mempunyai pengaruh signifikan terhadap profitabilitas.Zeitun (2012) yang menguji faktor-faktor yang mempengaruhi kinerja bank islam dan bank konvensional juga menemukan ada hubungan yang signifikan antara loan (pembiayaan) dengan profitabilitas. Bukhari and Kudus (2012) meneliti hubungan faktor internal dan eksternal yang mempengaruhi bank islam di Pakistan salah satunya hasilnya juga menemukan hubungan yang signifikan antara loan (pembayaan) dengan profitabilitas. Iszar dan Asutay (2007) yang meneliti bank islam di Indonesia dengan studi kasus di Bank Muamalat Indonesia (BMI) menemukan hubungan yang signifikan antara pembiayaan dengan profitabilitas. Sementara, Rahman dan Rochmanika (2012) tang melakukan penelitian bank islam di Indonesia dengan mengambil sampel 4 bank umum syariah menemukan bahwa pembiayaan berdasar jual beli dan pembiayaan berdasar bagi hasil secara signifikan mempengaruhi profitabilitas. Para peneliti tersebut di atas tidak melakukan menguji variabel pembiayaan secara rinci. Haron (1996) dan Rahman and rochmanika (2012) meneliti pembiayaan bagi hasil dan pembaiayaan berdasar jual beli. Sehingga perlu diteliti pengaruh jenis-jenis pembiayaan terhadap profitabilitas.

Untuk mengeneralisasikan populasi, maka sampel yang diambil sebaiknya bersifat homogin. Perbankan islam di Indonesia yang umurnya relatif baru dibanding bank konvensional, mempuanyai 
ukuran yang berbeda-beda sehingga sifatnya hetreogin. Oleh karena itu, perlu menyertakan variabel kontrol yang diharapkan bisa mengatasi permasalahan heterogenitas sampel. Karena ukuran bank syariah di Indonesia berbeda-beda, dalam penelitian ini ukuran perusahaan digunakan sebagai variabel kontrol. Akhter and Sadaqad (2011), Zeitun (2012), Mukhari and Qudus (2012) Idris et. al (2011) dan Gul et al (2011) menggunakan size sebagai variabel yang mempengaruhi profitabilitas.

\section{PENGEMBANGAN HIPOTESIS}

\subsection{Pembiayaan Berdasar Bagi Hasil dan Kinerja Keuangan}

Pembiayaan atau kredit pada perbankan konvensional, merupakan sumber utama penghasilan perbankan syariah. Semakin besar pembiayaan yang diberikan akan semakin besar kesempatan untuk memperoleh keuntungan. Haron (1996) menggunakan pembiayaan berdasar bagi hasil sebagai salah satu variabel yang mempengaruhi besar kecilnya profitabilitas. Bukhari and Kudus (2012) juga menemukan pembiayaan atau loan berpengaruh terhadap profitabilitas. Demikian pula dengan Izha dan Asutay (2007) juga menemukan hubungan antara pembiayaan dengan kemampuan perbankan menghasilkan laba. Rahman dan Rochmanika (2012) juga menguji pengaruh variabel pembiayaan berdasar bagi hasil terhadap profitabilitas. Pembiayaan berdasar konsep bagi hasil terdiri dari dua skim pembuayaan (Karim, 2010), yakni pembiayaan mudharabah dan pembiayaan musyarakah. Dengan demikian hipotesis yang diajukan dalam penelitian ini adalah:

$\mathrm{H}_{1} \quad$ Ada pengaruh positif pembiayaan mudharabah terhadap kinerja keuangan bank islam di Indonesia
$\mathrm{H}_{2} \quad$ Ada pengaruh positif pembiayaan musyarakah terhadap kinerja keuangan bank islam di Indonesia

\subsection{Pembiayaan Berdasar Marjin Laba dan Kinerja Keuangan}

Perbankan syariah dalam aplikasi pembiayaan, bisa menggunakan beberapa konsep. Selain konsep berdasar bagi hasil juga bisa menggunakan konsep berdasar marjin laba. Dengan konsep ini, nasabah dalam membayar kembali pinjamannya ditambah dengan marjin laba tertentu yang telah disepakati. Haron (1996) menduga ada pengaruh yang positif antara pembiayaan berdasar marjin laba (fund in mark-up) terhadap kinerja keuangan. Demikian pula dengan Rahman dan Rochmanika (2012) juga mengkaji pengaruh pembiayaan berdasar marjin laba dengan kemampuan menghasilkan laba. Pembiayaan dengan skim ini ada dua macam yakni pembiayaan murabahah. Selain pembiayaan berdasar dua konsep tersebut di atas, juga ada pembiayaan berdasar konsep sewa yang disebut sebagai pembiayaan Ijarah. Oleh karena itu bisa dibuat hipotesisnya sebagai berikut:

$\mathrm{H}_{3} \quad$ Ada pengaruh positif pembiayaan Murabahah terhadap kinerja keuangan bank islam di Indonesia

$\mathrm{H}_{4} \quad$ Ada pengaruh positif pembiayaan Ijarah terhadap kinerja keuangan bank islam di Indonesia

\subsection{Pembiayaan Berdasar Sosial dan Kinerja Keuangan}

Perbankan syariah didirikan bukan hanya untuk tujuan komersial, tetapi juga mempunyai fungsi sosial. Fungsi sosial ini direfleksikan dengan diijinkannya menerima dana yang berasal dari ZIS (zakat, infaq, dan sodaqah), dan menyalurkannya kepada yang berhak menerimanya melalui lembaga pengelola zakat. Dengan fungsi sosial ini diharapkan bisa semakin banyak menarik 
masyarakat untuk menjadi nasabahnya, sehingga dengan semakin banyaknya nasabah diharapkan akan semakin meningkatkan kinerja perbankan syariah. Dalam islam, jika umat mau bersedekah, maka Allah akan melipat gandakan rizkinya, seperti difirmankan dalam surat Al-Baqarah 162: Perumpamaan (nafkah yang dikeluarkan oleh) orang-orang yang menafkahkan hartanya di jalan Allah adalah serupa dengan sebutir benih yang menumbuhkan tujuh bulir, pada tiap-tiap bulir seratus biji. Allah melipat gandakan (ganjaran) bagi siapa yang Dia kehendaki. dan Allah Maha Luas (karunia-Nya) lagi Maha mengetahui. Dengan demikian, jika bank syariah memberikan pembiayaan dalam rangka kebajikan diharapkan akan meningkatkan kinerja bank syariah.

$\mathrm{H}_{5} \quad$ Ada pengaruh positif pembiayaan qordul hasan terhadap kinerja keuangan bank islam di Indonesia

\subsection{Ukuran Perusahaan dan Kinerja Keuangan}

Ukuran perusahaan yang

ditunjukkan dengan jumlah aset juga

mempengaruhi perbankan dalam

memperoleh laba. Semakin besar bank semakin besar kemampuannya untuk memberikan pembiayaan, karena mempunyai dana yang lebih besar dalam memberikan pembiayaan. Akhtar dan Ali (2011) menggunakan ukuran perusahaan sebagai variabel kontrol yang mempengaruhi profitabilitas. Zeitun (2012), Mukhari and Qudus (2012) Idris et. al (2011) dan Gul et al (2011) menggunakan size sebagai variabel yang mempengaruhi profitabilitas. Hipotesis yang selanjutnya adalah:

$\mathrm{H}_{6} \quad$ Ada pengaruh positif ukuran perusahaan terhadap kinerja keuangan bank islam di Indonesia

\section{METODE PENELITIAN}

\subsection{Populasi dan Sampel}

Populasi dalam penelitian ini adalah seluruh bank umum syariah yang ada di Indonesia. Sampai saat ini jumlah bank umum syariah sebanyak 11 bank umum syariah. Dari 11 bank tersebut, lama berdirinya bank syariah berbeda-beda, ada yang sudah berdiri selama 20 tahun (BMI), ada yang baru berumur 3 tahun yang didirikan tahun 2010 seperti Bank BNI Syariah, Bank BCA Syariah, Bank Victoria Syariah, bank BJB Syariah, dan Maybank Syariah.

Karena usia perbankan syariah berbeda-beda, maka sampel yang diambil sebanyak 8 bank syariah, dengan waktu yang berbeda-beda. Data yang diambil berupa data kuartalan seperti terlihat pada Tabel 1. di bawah: 
Tabel 1.

Sampel dan Jumlah Data

\begin{tabular}{|c|l||l||r|}
\hline No & \multicolumn{1}{|c|}{ Nama Bank } & \multicolumn{1}{|c|}{ Periode } & Jumlah Data \\
\hline \hline 1 & Bank Muamalat Indonesia & Kw 1 2008-kw 2 2013 & 22 \\
\hline 2 & Bank Syariah Mandiri & Kw 1 2008-kw 2 2013 & 22 \\
\hline 3 & Bank Mega Syariah & Kw 1 2008-kw 2 2013 & 18 \\
\hline 4 & Bank BRI Syariah & Kw 1 2009-kw 2 2013 & 16 \\
\hline 5 & Bank Syariah Bukopin & Kw 3 2009-kw 2 2013 & 15 \\
\hline 6 & Bank Panin Syariah & Kw 4 2009-kw 2 2013 & 12 \\
\hline 7 & Bank BCA Syariah & Kw 3 2010-kw 2 2013 & 140 \\
\hline 8 & Bank BNI Syariah & Kw 2 2010-kw 2 2013 & \\
\hline
\end{tabular}

\subsection{Variabel Penelitian}

Sesuai dengan kerangka konsep penelitian di depan, maka penelitian dalam ini terdapat dua variabel dependen, lima varabel independen dan satu variabel kontrol, dengan pengukuran variabel seperti terlihat pada Tabel 2. berikut:

Tabel 2.

Identifikasi dan Pengukuran Variabel

\begin{tabular}{|c||l||l|l||}
\hline \hline No & \multicolumn{1}{|c||}{ Variabel } & Notasi & \multicolumn{1}{||}{ Pengukuran } \\
\hline \hline 1 & Return on Equity & ROE & EAT/Equity \\
\hline \hline 2 & Net Profit Margin & NPM & EAT/Penghasilan Operasi \\
\hline \hline 3 & Pemb Murabahah & MUR & Pembiayaan Murabahah/Total Pembiayaan Murabahah \\
\hline \hline 4 & Pemb Mudharabah & MUD & Pembiayaan Mudharabah/Total Pembiayaan Mudharabah \\
\hline \hline 5 & Pemb Musyarakah & MUS & Pembiayaan Musyarakah/Total Pembiayaan Musyarakah \\
\hline \hline 6 & Pemb Ijarah & IJR & Pembiayaan Ijarah/Total Pembiayaan Ijarah \\
\hline \hline 7 & Pemb Qordul Hasan & QORD & Pembiayaan Qordul hasan/Total Pembiayaan Qordul Hasan \\
\hline \hline 8 & Ukuran Perusahaan & SIZE & Logaritma natural dari Total Assets \\
\hline
\end{tabular}

\subsection{Analisis Data}

Dalam rangka menjelaskan hubungan antara variabel dependen dengan variabel independen, maka perlu analisis statistik. Adapun alat analisis statistik dalam penelitian ini adalah analisis regresi regresi berganda. Regresi berganda adalah teknik regresi yang menjelaskan hubungan antara variabel dependen dengan variabel independennya. Persamaan regresi berganda tersebut adalah sebagai berikut:

$$
\begin{aligned}
R O E= & \beta_{0}+\beta_{1} M U D+\beta_{2} \text { MUS }+\beta_{3} M U R+ \\
& \beta_{4} I J R+\beta_{5} \text { Qord }+\beta_{6} \text { Size }+\varepsilon
\end{aligned}
$$

$$
\begin{aligned}
& \text { NPM }=\beta_{0}+\beta_{1} \text { MUD }+\beta_{2} \text { MUS }+\beta_{3} \text { MUR }+ \\
& \beta_{4} I J R+\beta_{5} \text { Qord }+\beta_{6} \text { Size }+\varepsilon \\
& \text { dimana, } \\
& \text { ROE }=\text { Return on equity } \\
& \text { NPM }=\text { Net Profit Margin } \\
& \text { MUD = Pembiayaan mudharabah } \\
& \text { MUS = Pembiayaan musyarakah } \\
& \text { MUR = Pembiayaan murabahah } \\
& \text { IJR } \quad=\text { Pembiayaan Ijarah } \\
& \text { Qord }=\text { Pembiayaan qordul hasan } \\
& \text { Size } \quad=\text { Ln Total Aktiva }
\end{aligned}
$$




\section{HASIL PENELITIAN}

\subsection{Statistik Deskriptif}

Seperti dijelaskan pada bab sebelumnya bahwa populasi dalam penelitian ini adalah perbankan syariah di indonesia yang jumlahnya sebanyak 11 bank umum syariah. Adapun sampel yang diambil adalah delapan bank umum syariah di Indonesia yang dipilih dengan metode purposive sampling. Dari data delapan bank umum syariah yang diambil secara kuartalan, diperoleh data statistik deskriptif seperti terlihat pada Tabel 3. berikut:

Tabel 3.

Statistik Diskriptif

\begin{tabular}{||l||r||r||r||r||r||}
\hline & \multicolumn{1}{|c|}{ Mean } & \multicolumn{1}{c|}{ Median } & \multicolumn{1}{c|}{ Maximum } & \multicolumn{1}{c|}{ Minimum } & \multicolumn{1}{c|}{ Std. Dev. } \\
\hline \hline ROE & 20.76829 & 10.96500 & 74.43000 & -63.72000 & 23.26342 \\
\hline \hline NPM & 7.40907 & 7.10500 & 16.14000 & -8.72000 & 4.09774 \\
\hline \hline MUR & 68.71157 & 68.58500 & 100.00000 & 12.93000 & 18.89331 \\
\hline \hline MUD & 10.84250 & 7.97000 & 41.07000 & 0.00000 & 9.66765 \\
\hline \hline MUS & 17.60150 & 14.89000 & 83.41000 & 0.00000 & 12.40900 \\
\hline \hline IJR & 2.84336 & 0.51000 & 64.20000 & 0.00000 & 7.70480 \\
\hline \hline QORD & 4.96586 & 3.12000 & 28.88000 & 0.00000 & 5.70622 \\
\hline \hline SIZE & 15.60555 & 15.66573 & 17.88426 & 11.99318 & 1.31409 \\
\hline
\end{tabular}

Kinerja perbankan yang diukur dengan return on equity menunjukkan ratarata yang cukup tinggi yakni sebesar 20,76\%, dengan ROE paling tinggi sebesar 74,43\% yang diperoleh oleh Bank Syariah Mandiri (BSM) pada semester 4 tahun 2011. Namun ada juga bank umum syariah yang tingkat ROE-nya negatif sebesar $63.72 \%$ yang disebabkan bank tersebut baru berdiri yakni Bank BNI Syariah diawal beroperasinya tahun 2010. Dilihat dari net profit margin (NPM) menunjukkan rata-rata sebesar $7,41 \%$ dengan NPM paling tinggi sebesar $16.14 \%$ yang diperoleh oleh Bank Mega Syariah pada kwartal kedua tahun 2011. Sedangkan NPM paling rendah sebesar -8,72\% dialami oleh Bank Panin Syariah diawal beroperasinya kuartal pertama tahun 2010.

Pembiayaan Murabahah yang menggunakan konsep margin laba rata-rata sebesar 68,71\%, dengan pembiayaan paling tinggi 100\% yang dilakukan oleh Bank Mega Syariah. Pembiayaan yang diberikan oleh Bank Mega Syariah ini memang lebih dari
95\% dalam bentuk pembiayaan murabahah. Sedangkan pembiayaan murabahah yang paling rendah sebesar 12,93\% yang diberikan oleh Bank BCA Syariah pada awal pendiriannya di tahun 2010.

Sementara pembiayaan mudharabah masih sangat kecil karena rata-ratanya hanya 10,84\%. Pembiayaan paling tinggi diberikan oleh Bank Panin Syariah sebesar 41,07\% pada kuartal 2 tahun 2012. Namun ada bank yang sama sekali tidak memberikan pembiayaan berdasar bagi hasil ini (minimum 0,00\%) yakni Bank Mega Syariah di tahun 2011, 2012 dan tahun 2013.

Pembiayaan musyarakah yang diberikan oleh perbankan syariah rata-rata sebesar 10,84\%, angka ini menunjukkan masih kecilnya bank syariah dalam memberikan pembiayaan berdasar bagi hasil. Pembiayaan paling tinggi sebesar 41,07\% diberikan oleh Bank Panin di awal pendiriannya tahun 2010. Sedangkan paling rendah sebesar $0 \%$ artinya ada bank syariah yang sama sekali tidak memberikan 
pembiayaan jenis ini, yakni Bank Mega Syariah.

Pembiayaan ijarah yang diberikan rata-rata sebesar $2.84 \%$ dan yang paling tinggi sebesar $64.2 \%$ diberikan oleh Bank BCA Syariah diawal pendiriannya tahun 2010 yang terus menurun hingga pada pertengahan tahun 2013 tinggal sekitar 6\%. Masih banyak bank umum syariah yang tidak memberikan pembiayaan ijarah ini, yang diindikasikan nilai minimumnya sebesar 0\%. Bank yang tidak memberikan pembiayaan ijarah ini misalnya Bank Mega Syariah, Bank Panin Syariah, dan Bank Bukopin Syariah.

Yang cukup membanggakan adalah pembiayaan berdasar prinsip sosial atau sering disebut pembiayaan qordul hasan menunjukkan angka yang menggembirakan.
Rata-rata pembiayaan ini 4,96\% dengan pembiayaan tertinggi sebesar $28,88 \%$ yang diberikan oleh Bank BRI Syariah di pertengahan tahun 2011. Namun demikian juga masih ada bank yang tidak memberikan pembiayaan berdasar prinsip sosial ini karena menurut data, minimum pembiayaan ini menunjukkan angka $0,00 \%$.

\section{$5.2 \quad$ Uji Hipotesis}

\subsubsection{Pengaruh Pembiayaan terhadap} ROE

Setelah dilakukan proses olah data secara statistik dengan menggunakan bantuan program eviews, diperoleh hasil pengaruh variabel independen terhadap variabel dependennya seperti pada Tabel 4 . di bawah ini.

Tabel 4.

Hasil Regresi Berganda

\begin{tabular}{||c||r||r||r|r||}
\hline \multirow{2}{*}{ Variabel } & \multicolumn{2}{|c||}{ ROE } & \multicolumn{2}{c|}{ NPM } \\
\cline { 2 - 5 } & Koefisien & \multicolumn{1}{c|}{ Prob } & \multicolumn{1}{c|}{ Koefisien } & \multicolumn{1}{c|}{ Prob } \\
\hline \hline C & -1962.693 & 0.3068 & -6390.973 & 0.0071 \\
\hline \hline MUR & 19.56677 & 0.0382 & 63.91615 & 0.0071 \\
\hline \hline MUD & 19.5796 & 0.3079 & 63.78583 & 0.0082 \\
\hline \hline MUS & 19.50626 & 0.0497 & 63.73404 & 0.0173 \\
\hline \hline IJR & 19.56606 & 0.3083 & 64.02759 & 0.027 \\
\hline \hline QORD & 19.50816 & 0.0961 & -0.112709 & 0.0385 \\
\hline SIZE & 0.546272 & 0.0000 & 0.749513 & 0.0016 \\
\hline
\end{tabular}

Pembiayaan murabahah mempunyai pengaruh yang positif dan signifikan terhadap ROE yang ditunjukkan dengan besarnya probabilitas t-statistik sebesar 0,0382 lebih kecil dibanding dengan tingkat signifikansinya 5\%, ini menunjukkan bahwa kinerja bank syariah yang diukur dengan laba untuk pemegang saham dipengaruhi oleh besarnya pembiayaan murabahah.

Pada pembiayaan berdasar bagi hasil, ada temuan yang menarik yakni untuk pembiayaan mudharabah ternyata tidak mempunyai pengaruh terhadap ROE yang ditandai dengan hasil probabilitas tstatistiknya sebesar 0,3079 jauh lebih besar dibanding dengan tingkat signifikansinya 5\%. Sedangkan pembiayaan musyarakah mempunyai pengaruh yang signifikan terhadap ROE sebab probabilitas tstatistiknya sebesar 0,0497 lebih kecil dibanding tingkat signifikannya.

Pembiayaan ijarah merupakan pembiayaan yang berdasarkan atas sewa menghasilkan nilai probabilitas sebesar 0.3083 lebih besar dibanding tingkat signifikansinya $5 \%$, sehingga pembiayaan 
ijarah tidak mempunyai pengaruh terhadap ROE. Demikian pula dengan pembiayaan qordul hasan juga tidak mempunyai pengaruh yang signifikan terhadap ROE karena probabilitas t-statistiknya lebih besar dibanding dengan yang disyaratkan. Sementara ukuran perusahaan (SIZE) mempunyai pengaruh yang signifikan terhadap ROE yang ditandai dengan nilai probabilitas t-statistiknya sebesar 0,000 lebih kecil dibanding tingkat signifikansi yang disyaratkan.

\subsubsection{Pengaruh Pembiayaan terhadap NPM}

Sementara pengaruhnya terhadap variabel independen NPM, pembiayaan murabahah konsisten mempunyai pengaruh yang positif dan signifikan terhadap NPM yang ditunjukkan dengan besarnya probabilitas t-statistik sebesar 0,0071 lebih kecil dibanding dengan tingkat signifikansinya 5\%. Sedangkan pada pembiayaan berdasar bagi hasil, baik pembiayaan mudharabah maupun pembiayaan musyarakah mempunyai pengaruh signifikan terhadap NPM yang ditandai dengan hasil probabilitas tstatistiknya sebesar 0,0082 untuk pembiayaan mudharabah dan 0,0082 jauh lebih besar dibanding dengan tingkat signifikansinya $5 \%$.

Pembiayaan ijarah juga mempunyai pengaruh yang positif dan signifikan terhadap NPM dengan nilai probabilitas sebesar 0.0270 lebih besar dibanding tingkat signifikansinya $5 \%$, sehingga pembiayaan ijarah mempunyai pengaruh terhadap NPM. Demikian pula dengan pembiayaan qordul hasan juga mempunyai pengaruh yang signifikan terhadap NPM tetapi pengaruhnya negatif dengan nilai probabilitas tstatistiknya sebesar 0,0385 lebih kecil dibanding dengan yang disyaratkan. Sementara ukuran perusahaan (SIZE) mempunyai pengaruh yang signifikan terhadap NPM yang ditandai dengan nilai probabilitas t-statistiknya sebesar 0,0016 lebih kecil dibanding tingkat signifikansi yang disyaratkan.

\subsection{Pembahasan}

Murabahah merupakan pembiayaan yang berbasis marjin laba ini mempunyai pengaruh yang positif dan signifikan terhadap kinerja bank syariah yang diukur dengan return on equity maupun net profit margin (NPM). Kondisi ini disebabkan jumlah pembiayaan murabahah merupakan pembiayaan yang porsinya paling besar dibanding dengan jenis pembiayaan lainnya. Bahkan pada akhir tahun 2012, Bank Mega Syariah dan Maybank Syariah mempunyai porsi pembiayaan murbahah lebih dari 99\%, artinya hampir semua pembiayaan yang diberikan berbasis margin laba. Sedangkan Bank BRI Sayiah dan Bank BNI Syariah porsi pembiayaan ini mencapai diatas $75 \%$. Hasil penelitian ini sejalan dengan temuan Haron (1996) yang menemukan pembiayaan berdasar marjin laba berpengaruh positif dan signifikan terdap kinerja keuangan. Demikian pula dengan hasil penelitian Rahman dan Rochmanika (2012) yang menemukan pengaruh yang positif dan signifikan antara pembiayaan berdasar jual beli dengan profitabilitas bank umum syariah. Oktarini (2012) yang melakukan peneltian terhadap Bank Muamalat Indonesia juga menemukan pengaruh pembiayaan murabahah dengan profitabilitas. Pembiayaan murabahah juga mempunyai pengaruh yang positif dan signifikan terhadap net profit margin (NPM), hal ini disebabkan sumbangan terbesar dari keuntungan operasi bank umum syariah berasal dari pembiayaan murabahah.

Pembiayaan mudharabah yang berbasis profit and loss sharing (PLS) ternyata mempunyai pengaruh yang tidak 
signifikan terhadap ROE. Ini bisa dimengerti, sebab pembiayaan ini tidak banyak dimanfaatkan oleh perbankan syariah yang dikarenakan pembiayaan ini mempunyai risiko yang besar (Ascarya dkk, 2013). Bahkan Bank Mega Syariah tidak memberikan pembiayaan ini sama sekali sementara Bank Muamalat Indonesia sebagai bank pertama di Indonesia tahun 2012 hanya memberikan porsi $5 \%$ untuk pembiayaan mudharabah. Temuan ini sesuai dengan hasil penelitian Oktarini (2012) yang menemukan pembiayaan mudharabah berpengaruh positif tetapi tidak signifikan terhadap profitabilitas. Tetapi Rahman dan Rochmanika (2012) menemukan pengaruh yang signifikan antara pembiayaan bagi hasil dengan kinerja bank syariah. Demikian pula dengan Haron (1996) juga menemukan hal yang sama. Sayangnya Haron (1996) dan Rahman dan Rochmanika (2012) tidak memisahkan pembiayaan berdasar bagi hasil ke dalam pembiayaan mudharabah dan musyarakah. Namun pembiayaan mudharabah telah memberikan sumbangan terhadap peningkatan penghasilan operasional bank yang diindikasikan pengaruh positif dan signfikan terhadap NPM.

Sedangkan pembiayaan musyarakah mempunyai pengaruh positif dan signifikan terhadap kienrja bank syariah baik diukur dengan ROE mapun NPM. Temuan ini sesuai dengan fakta bahwa bank syariah lebih menyukai pembiayaan berdasar bagi hasil dengan model musyarakah, sebab dengan model ini bank bisa ikut dalam manajemen perusahaan nasabah. Bank Muamalat Indonesia (BMI) tahun 2012 mmberikan pembiayaan ini sebesar lebih 23\% sedangkan pembiayaan mudharabah hanya sekitar 5\%, demikian pula Bank BCA Syariah memberikan pembiayaan ini lebih 30\%. Haron (1996) yang melakukan penelitian di beberapa negara Arab menemukan hal yang sama, demikian pula dengan Rahman dan Rochmanika (2012) juga menemukan pengaruh yang signifikan antara pembiayaan bagi hasil dengan kinerja bank syariah. Sedangkan Oktarini (2012) yang sampelnya hanya BMI menemukan hal sebaliknya, pembiayaan musyarakah pengaruhnya tidak signifikan terhadap profitabilitas. Pembiayaan musyarakah juga memberikan sumbangan terhadap peningkatan penghasilan operasional bank yang diindikasikan pengaruh positif dan signfikan terhadap NPM.

Pembiayaan ijarah yang menggunakan konsep sewa, ternyata mempunyai pengaruh yang tidak signifikan terhadap ROE, hal ini disebabkan porsi pembiayaan ini masih sangat sedikit. Bank Syariah Mandiri (BSM) sampai akhir tahun 2012 hanya memberikan porsi 0,41\%, BMI memberikan porsi 0,51\%, Bank BRI Syariah memberikan porsi $1,22 \%$, bahkan beberapa bank tidak memberikan sama sekali pembiayaan ini, seperti Bank Mega Syariah, Bank Panin Syariah, dan Bank Syariah Bukopin. Namun pembiayaan ijarah ini masih memberikan sumbangan terhadap peningkatan laba bank yang diindikasikan denga pengaruh positif dan signfikan terhadap NPM.

Pembiayaan qordul hasan yang berbasis sosial pengaruhnya juga tidak signifikan terhadap ROE, padahal beberapa bank syariah memberikan pembiayaan ini dalam jumlah yang besar. BMI misalnya akhir tahun 2012 posisi pembiayaan qord sebesar 1,27 triliun atau 3,62\% dari total pembiayaan, BSM sebesar Rp 6,13 triliun (13,18\%), dan BRI Syariah Rp 1,44 triliun (11,38\%). Angka-angka ini menunjukkan bahwa beberapa bank syariah sangat peduli dengan pengusaha dhuafa'. Namun demikian ada beberapa bank syariah yang tidak memberikan pembiayaan berbasis sosial ini seperti Bank Panin Syariah, Bank BCA 
Syariah, Bank Victoria Syariah, dan Maybank Syariah. Pengaruh yang tidak signifikan ini mengindikasikan bahwa besarnya pembiayaan ini tidak memberikan pengaruh terhadap ROE karena memang pembiayaan ini tidak menyumbangkan penghasilan riil, bahkan pengaruhnya terhadap NPM signifikan tetapi negatif.

\section{KESIMPULAN}

Dari hasil kajian teori, kajian pembahasan diatas, maka dapat ditarik kesimpulan:

- Pembiayaan murabahah yang merupakan pembiayaan berdasar marjin laba mempunyai pengaruh yang signifikan terhadap kinerja bank syariah. Pembiayaan ini merupakan pembiayaan yang banyak dimanfaatkan oleh bank, karena pembiayaan ini paling mudah untuk diaplikasikan. Hasil penelitian ini sesuai dengan temuan Haron (1996), Rahman dan Rochmanika (2012), dan Oktarini (2012).

- Pembiayaan mudharabah yang berbasis bagi hasil belum banyak diaplikasikan oleh bank, karena masih dianggap sangat berisiko (Ascarya). Hal ini menyebabkan sumbangannya terhadap ROE tidak signifikan. Hasil penelitian ini sejalan dengan temuan Oktarini (2012). Sedangkan pembiayaan musyarakah mempunyai pengaruh yang signifikan terhadap peningkatan kinerja (ROE dan NPM), hal ini karena bank lebih menyukai memberikan pembiayaan musyarakah dibanding mudharabah, sebab dalam pembiayaan musyarakah, bank bisa ikut dalam manajemen perusahaan nasabah. Temuan Haron (1996) dan Rahman dan Rochmanika (2012) mendukung hasil penelitian ini.

- Pembiayaan ijarah mempunyai pengaruh yang tidak signifikan terhadap kinerja bank syariah (ROE). Pembiayaan ini juga belum banyak dimanfaatkan oleh bank bank syariah, sehingga sumbangannya terhadap ROE belum signifikan.

- Pembiayaan qord yang berbasis sosial pengaruhnya juga tidak signifikan, namun demikian ada semangat dari bank syariah untuk memberikan pembiayaan ini yang ditunjukkan oleh besarnya pembiayaan ini diberikan kepada nasabah, walaupun ada sebagian bank syariah yang belum menggunakan pembiayaan ini.

Dengan kesimpulan yang demikian, peneliti memberikan saran agar bank syariah bisa lebih mengembangkan produk pembiayaan yang berbasis bagi hasil. Sebab pada dasarnya yang paling direkondasikan dalam ekonomi islam adalah prinsip bagi hasil. Karena pembiayaan berdasar bagi hasil inilah yang benar-benar mengandung prinsip keadilan. Sementara pembiayaan murabahah yang berbasis jual beli dengan marjin laba sebaiknya mulai dikurangi, sebab pembiayaan ini terkesan bank sebagai pengecer (retailer). Sehingga bank dianggap sebagai pedagang. 


\section{DAFTAR PUSTAKA}

Acaravci, Songul Kakilli and Ahmet Ertugrul Calim, 2013, “Turkish Banking Sector’s Profitability Factors”, International Journal of Economics and Financial Issues, 3(1), 27-41

Ani, W.U., et.al., 2012, "An Empirical Assessment of the Determinant on Bank Profitability in Nigeria: Bank Characteristics Panel Evodence”, Journal of Accounting and Taxation, 4(3), 38-43.

Antonio, Muhammad Syafi'i., 2001, Bank Syariah: Dari Teori ke Praktik, Gema Insani Press, Jakaarta

Akhtar, Muhammad Farhan., Khizer Ali, and Shama Sadaqat., 2011, "Factors Influencing the Profitability of Islamic Bank of Pakistan”, International Research Journal of Finance and Economics, 66, 125-132

Akhter, Waheed., Ali Raza, Orangzab, and Muhammad Akram., 2011, "Efficiency and Performnace of Islamic Banking: The Case of Pakistan”, Far East Journal of Psychology and Business, 2(2), 54-70

Al-Omar, Husain., and Abdullah Al-Mutairi, 2008,” Bank-Specific Determinant of Profitability: The Case of Kuwait”, Journal of Economics and Administrative Science, 24(2), 20-34

Arianti N. P, Wuri and Harjum Muharam, 2012, “Analisis Pengaruh Dana Pihak Ketiga (DPK), Capital Adequacy Ratio (CAR), Non Performance Financing (NPF), dan Return on Asset (ROA) terhadap Pembiayaan pada Perbankan Syariah”, Working Paper, eprint.undip.ac.id/32445/jurnal_wuri

Arifin, Noraini Mohd., 2012,” Liquidity Risk Management and Financial Performance in Malaysia: Empirical Evidence from Islamic Banks", Aceh International Journal of Social Science, 1(2), 68-75

Ascarya, dkk., 2013, "Strategi Meningkatkan Preferensi Perbankan Syariah Indonesia dalam Menggunakan Pembiayaan Bagi Hasil”, Working Paper, Bank Indonesia

Bashir, Abdel-Hameed M., 2003, "Determinant of Profitability in Islamic Bank: Some Eviden from the Middle-East”, Islamic Economic Studies, 11(1), 31-57

Bukhari, Syeda Anum Javed., and Rana Abdul Qudous, 2012, "Internal and External Determinant of Profitability of Banks: Evidence from Pakistan”, Interdisciplinary Journal of Contemporary Research in Business, 3(9), 1037-1058

El-Tiby, Amr Mohamed., 2011, Islamic Banking: How to manage and Improve Profitability, John Wiley \& Sons, New Jersey

Ghayad, Racha., 2008, “Corporate Governance and the Global Performance of Islamic Banks”, Journal of Humanomics, 24(3), 207-216

Gull, Sehrish., Faiza Irshad, and Khalid Zaman., 2011, “Factors Affecting Bank Profitability in Pakistan”, The Romanian Economic Journal, 14(39), 61-87

Haron, Sudin, 1996, “The Effect of Management Policy on The Performance of Islamic Banks”, Asia Pasific Journal of Management, 13(2), 63-76 34-36

1997, "Determinant of Islamic Bank Profitability: Some Evidence”, Jurnal Pengurusan, 16, ----- and Bala Shanmugam, Islamic Banking System: Concept \& Application, Pelanduk Publications, Malaysia

Hidayat, Irman Pirman., and Hana Hujaemah, "Pengaruh Pemberian Kredit terdahap Loan to Deposit Ratio dan Dampaknya pada Pendapatan Bank”, Working Paper,

Idris, Asma' Rashidah., et.al., 2011, "Determinant of Islamic Banking Institutions' Profitability in Malaysia”, World Applied Journal, 12 (special issue).

Ismail, AH., 1992, Islamic Banking in Malaysia: Some Issues, Problem and Prospect, Kuala Lumpur: Bank Islam Malaysia Berhad

Izhar, Hylman and Mehmet Asutay., 2007, "Estimating the Profitability of Islamic Banking: Evidence from Bank Muamalat Indonesia”, Review of Islamic Economics, 11(2), 17-29

Karim., Adiwarman A., 2010, Bank Islam: Analisis Fiqih dan Keuangan, Raja Grafindo Persada, Jakarta

Kasri, Rahmatina K., and Salina Hj. Kasim., 2009, "Empirical Determinant of Saving in the Islamic Bank: Evidence from Indonesia”, JKAU: Islamic Economics, 22(2), 181-201 
Kuppusany, Mudiarasan., Ali Salman and Ananda Samudhram, 2010, "Measurement of Islamic Banks Performance Using a Syariah Conformity and Probablility Model”, Review of Islamic Economic, 13(2), 35-48

Lewis, Mervyn K., and Latifa M. Algaoud, 2001, Islamic Banking, Edward Elgar Publishing Limited, Northampton

Moin, Muhammad Shehzad., 2008, Performance of Islamic Bank and Conventional Bank in Pakistan: A Comparative Study, Thesis Master Degree, School of Technology and Society, University of Skovde

Muhammad, 2005, Manajemen Bank Syariah, UPP AMP YKPN, Yogyakarta

Oktarini, Yesi., 2012, "Pengaruh Pembiayaan Musyarakah, Mudharabah, dan Murabahah terhadap profitabilitas”, Kertas Kerja, Fakultas Ekonomi Universitas Siliwangi

Pratin and Akhyar Adnan., 2005,” Analisis Hubungan Simpanan, Modal Sendiri, NPL, Prosentase Bagi Hasil dan Markup Keuntungan terhadap Pembiayaan pada Perbankan Syariah: Studi Kasus pada Bank Muamalat Indonesia (BMI)”, Jurnal Sinergi: Kajian Bisnis dan Manajemen, Edisi Khusus, 35-52

Rachmawati, Erna and Ekki Syamsulhakim, 2004, "Factors Affecting Mudharaba Deposits in Indonesia, Working Paper", International Islamic banking and Finance Conference

Rahman, Aulia Fuad and Ridha Rochmanika,. 2012, "Pengaruh Pembiayaan Jual Beli, Pembiayaan Bagi Hasil, dan Ratio Non Performance Financing terhadap Profitabilitas Bank Umum Syariah di Indonesia”, ejournal.uin-malang.ac.id/index.php/.../1768/pdf

Raquib, Abdur., 2007, Principle \& Practisce of Islamic Banking, Panam Press Ltd, Dhaka

Rivai, Veithzal., and Andria Permata Veithzal, and Ferry N. Idrus., 2007, Bank and Financial Institution Management, Raja Grafindo Perkasa, Jakarta

Rosly, Saiful Azhar., 2004, The Inseparable Shari' and Tabi’ Principle in Business Strategy, DinarStandar, Business Strategies for Muslim World, 3

Satrio, Dias and Rangga Bagus Subegti., 2010,” Determinasi Penyaluran Kredit Bank Umum di Indonesia Periode 2006-2009”, Jurnal Keuangan dan Perbankan, 14(3), 425-424

Siamat, dahlan., 2005, Manajemen Lembaga Keuangan: Kebijakan Moneter dan Perbankan, Lembaga Penerbit Fakultas Ekonomi Universitas Indonesia, Jakarta

Siraj, K. K., and Sudarsanan Pillai, 2012, "Comparative Study on Performance of Islamic Bank and Convensional Bank in GCC Region”, Journal of Applied Finance and Banking, 2(3),

Srairi, Samir Abderrazek., "Faccotrs Influencing the Profitability of Conventional and Islamic Banks in GCC Countries", Review of Islamic Economics, 11(1), 5-30

Sudarsono, Heri., 2003, Bank dan Lembaga Keuangan Syariah, Penerbit Ekonisia, Yogyakarta

Syafri, 2012, "Factors Affecting Bank Profitability in Indonesia”, Paper: The 2012 International Conference on Business and Management, Thailand

Vong, Anna. P.I and Hoi Sin Chan, 2011, "Determinant of Bank Profitability in Macau”, Working Papaer: Faculty of Business and Administration, University of Macau

Zeitun, Rami., 2012, "Determinant of Islamic and Conventional Banks Performance ini GCC Countries Using Panel data Analysis”, Global Econony and Finance Journal, 5(1), 53-72 